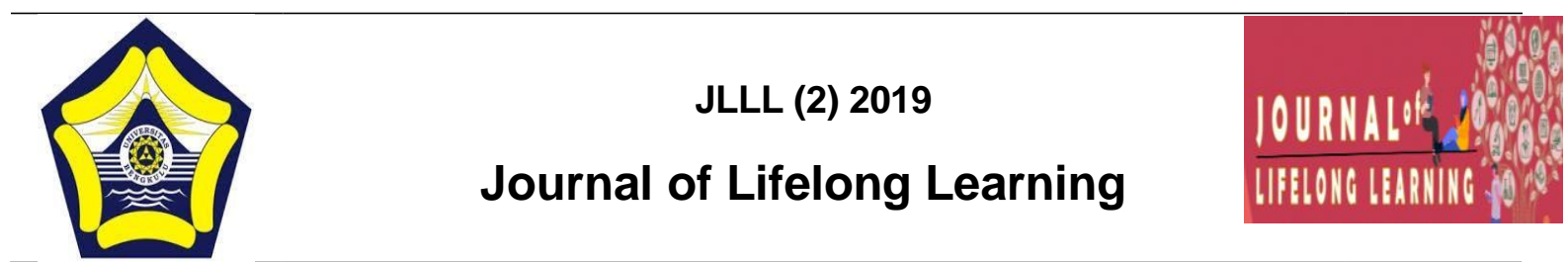

\title{
PEMASARAN PRODUK MENJAHIT \\ PADA PROGRAM PKBM MEKAR SARI
}

\author{
Ida Maeyeni' ${ }^{1}$, Agus Z Rahmad², Ririn Gusti ${ }^{3}$ \\ ${ }^{1}$ Nonformal Education, University of Bengkulu, Indonesia, idamaryeni@gmail.com \\ ${ }^{2}$ Nonformal Education, University of Bengkulu, Indonesia, aguszainal@gmail.com \\ ${ }^{3}$ Nonformal Education, University of Bengkulu, Indonesia, riringusti@unib.ac.id
}

\begin{abstract}
The objectives of this study were: (1) Knowing the Background of the Sewing Program at PKBM Mekar sari (2) Knowing the Implementation of Sewing Learning at PKBM Mekar Sari (3) Knowing the Marketing of Sewing Products in the Mekar Sari PKBM Program (4) Knowing the Profit and Loss Calculations of Sewing Businesses in PKBM Mekar Sari. Research methods used qualitative methods with descriptive approaches. The participants of the study were Ibuk Titin Sumarni Anjani as Chairman of PKBM Mekar Sari and Simultaneously sewing coach, Ibuk Wulan Widia Astuti as sewing coach, and Siasmawati as sewing coach and Secretary. Data collection techniques used were non-participant observation, structured interviews, and documentation. To test the validity and reliability of data using triangulation of sources, techniques, and time. Based on the analysis that has been carried out that the sewing program in PKBM Mekar sari Padang Kedondong Village, Tanjung Kemuning District, Kaur Regency includes a sewing program. During the implementation of 2x week activities, the coach's role coordinates in the activity, the funds obtained from the Government budget, while the supporting factors of the facility while inhibiting the lack of financial factors. Innovative business carried out by time discipline. Then the supervision is carried out by the trainer directly by observing the activities carried out once every two weeks of training.
\end{abstract}

Keywords: Program, To Sew, PKBM.

(C) 2019 Dept of Nonformal Education UNIB

Address correspondence:

e-ISSN

JI. W.R. Supratman, Kandang Limun, Muara Bangka Hulu,

Kota Bengkulu, Bengkulu 38371 


\section{PENDAhUluan}

Pusat Kegiatan Belajar Masyarakat (PKBM) adalah suatu wadah berbagai kegiatan pembelajaran Masyarakat yang diarahkan pada pemberdayaan potensi untuk menggerakan pembangunan di Bidang sosial,ekonomi dan masyarakat budaya. PKBM dibentuk bertujauan untuk memperluas kesempatan warga belajar Masyarakat khususnya yang tidak tidak mampu untuk meningkatkan pengetahuan, keterampilan, dan sikap mental yang diperlukan untuk mengembangkan diri dan meningkatkan kualitas hidup dan meningkatkan Tarap hidup , terutama masalah perekonomian mereka.

Sedangkan program menjahit yang dimaksud dalam penelitian ini adalah program menjahit yang ada di desa Padang Kedondong. Salah satu yang merupakan jenis program PKBM Mekar Sari adalah Usaha menjahit yang beralamat di desa Padang Kedondong Kecamatan Tanjung Kemuning Kabupaten Kaur.program Menjahit ini adalah PKBM Mekar Sari dikelola oleh Ibu titin anjani, PKBM ini mulai berdiri pada tahun 2007.Program Menjahit ini pada awalnya hanya dikerjakan oleh Ibutitin dan Ibu wina saja,tetapi seiring dengan permintaan pasar dan kurangnya jumlah produksi jahitan yang dibuat maka mulailah banyak masyarakat sekitar yang bekerja pada program menjahit yang sampai saat ini.walaupun di Kecamatan Tanjung Kemuning terdapat beberapa PKBM tetapi di PKBM Mekar Sari ini Terdapat Keunggulan dalam Program Menjahit sedangkan di PKBM yang lain tidak terdapat program tersebut.

\section{METODE}

Metode penelitian yang digunakan pada penelitian ini adalah penelitian kualitatif. "Penelitian kualitatif adalah metode penelitian yang berlandaskan pada filsafat postpositivisme, digunakan untuk meneliti pada kondisi objek yang alamiah, dimana peneliti adalah sebagai instrument kunci, teknik pengumpulan data dilakukan secara triangulasi (gabungan), analisis data bersifat induktif/kualitatif, dan hasil penelitian lebih menekankan makna dari pada generalisasi

\section{HASIL DAN PEMBAHASAN}

Untuk memasarkan produk Hasil Jahitan dapat dilakukan dengan menitipkannya melalui toko-toko atau butik fashion yang ada di sekitar .Selain itu juga bisa memasarkannya dengan menerima pesanan dari konsumen, baik melayani partai besar maupun partai kecil. Sehingga penjualan produk jahitan meningkat, dan bisa dikenal pasar yang lebih luas.

Dan bisa memasarkannya dengan memanfaatkan promosi dari mulut ke mulut, sehingga informasi mengenai produk dapat menyebar di kalangan masyarakat. Strategi promosi pengenalan produk, juga dapat dilakukan dengan cara mengikuti pameran-pameran yang belakangan ini sering diadakan oleh berbagai pihak.Tidak hanya itu, seiring dengan perkembangan jaman juga bisa memasarkannya melalui internet.

\section{PENUTUP}

Berdasarkan temuan dilapangan, peneliti dapat mengambil kesimpulan bahwa:

Pemasaran produk Hasil Jahitan dapat dilakukan dengan menitipkan nya melalui tokotoko atau butik fashion yang ada di sekitar. Selain itu juga bisa memasarkannya dengan menerima pesanan dari konsumen, baik melayani partai besar maupun partai kecil. Sehingga penjualan produk jahitan meningkat, dan bisa dikenal pasar yang lebih luas Dan bisa 
memasarkannya dengan memanfaatkan promosi dari mulut ke mulut, sehingga informasi mengenai produk dapat menyebar di kalangan masyarakat. Strategi promosi pengenalan produk, juga dapat dilakukan dengan cara mengikuti pameran-pameran yang belakangan ini sering diadakan oleh berbagai pihak.Tidak hanya itu, seiring dengan perkembangan jaman juga bisa memasarkannya melalui internet.

Berdasarkan hasil pembahasan dan kesimpulan peneliti yang telah dikemukakan, maka peneliti ingin menyampaikan saran yaitu :

1. Bagi instruktur dan warga belajar hendaklah lebih disiplin agar pelaksanaan pembelajaran pada program menjahit di PKBM Mekar Sari dapat berjalan dengan baik dan keterampilan dapat meningkat.

2. Bagi pengelola hendaklah membuat suatu inovasi baru dalam pembelajaran. Seperti, inovasi dalam pembelajaran untuk terus meningkatkan program -program menjahit tidak hanya mem praktekan.

3. Warga belajar diharapkan lebih semangat dan kompak lagi dalam proses program menjahit.

\section{REFERENSI}

Arikunto, Suharsimi.2006. Dasar-Dasar Evaluasi Pendidikan.Jakarta :Bumi Aksara

Best,John.W.1982 Metodeologi Penelitian Dan Pendidikan Surabaya: Usaha Nasional

Davis Gordon B,1994,Management Sistem Information,TP.Midas Surya Grafindo,Jakarta

Drs.H.Malayu,S.P.Hasibuan,2007.managemen sumber daya manusia,jakarta:Cetakan 9.PT.Bumi Aksara

Hadi, Sutrisno. 1986. Metodologi Research. Yogyakarta: Andi Offset.

I Made wirartha.2006. Metodologi Penelitian Sosial Ekonomi.Yogyakarta Andi Offset

Moleong ,laxi,2002,Metodeologi penelitian kualitatif.Bandung:PT Remaja Rosdakarya.

Niwawi,Hadari,2000, Manajemen Sumber Daya Manusia Untuk Bisnis Yang Kompetitif, Gajah Mada University Press, Yogyakarta.

Sudjana, Nana. 2004. Dasar-dasar Proses Belajar Mengajar. Bandung :Sinar Baru Algensido Offset.

Rudianto, 2006 Akutansi Manajemen.Jakarta: PT Gramedia.

sugiyono.2010.metode penelitian kuantitatif dan kualitatif .bandung .Alfabeta.

Sudjana, Djudju, (2004); Pendidikan Non Formal, Fallah Production, Bandung

Yulikuspartono, 2009. Pengantar Logaritma dan Algoritma, Yogyakarta: Andi. 